\title{
The Concept for the Development of Biogas as Renewable Energy in Rural Indonesia
}

\author{
Achmad T. Nugraha ${ }^{1 *}$, Gunawan Prayitno ${ }^{2}$, Daafi Al Himah ${ }^{2}$ \\ ${ }^{1}$ Department of Agribusiness, Syarif Hidayatullah State Islamic University, Jakarta 15412, Indonesia \\ ${ }^{2}$ Regional and Urban Planning Department, Faculty of Engineering, Universitas Brawijaya, Malang 65145, Indonesia
}

Corresponding Author Email: achmad.tjachja@uinjkt.ac.id

https://doi.org/10.18280/ijsdp.160618

Received: 14 May 2021

Accepted: 30 July 2021

\section{Keywords:}

biogas, energy independent village,

supply demand analysis

\begin{abstract}
Indonesia policy in Presidential Regulation No. 5 of 2006 on National Energy Management 2006-2025 states that one of its tasks is the ethical and sustainable management of energy, including the maintenance of environmental functions and increasing the role of new and renewable energy to $5 \%$ by 2025 . In response to this problem, an effort is needed to meet the Indonesian people's energy needs. One of the programs of the Indonesian government is the implementation of an energy-independent village program. Jimbaran Village is one of the villages that have the potential to develop into an Energy Independent Village. The majority of Jimbaran Village residents work as cattle breeders, i.e., 1,663 families. The average farmer in Jimbaran Village has 3-4 cows/family heads with a total of 5,976 dairy cows. However, of the many existing breeders, no one has processed cow waste into biogas, which is a source of renewable energy. Animal waste may also be used to develop the clove and coffee plantation sector when processed into compost. Livestock waste is only dumped into sewers or human yards, so the environment is very polluting. It is, therefore, necessary to process livestock waste into biogas or compost. The analysis technique used in calculating the plan for the production of communal biogas is the analysis of supply, demand, and energy performance. Based on the calculation of the energy performance, it can be seen that the energy performance is more than 100 percent, which means that there is an excess of energy generated by existing biogas. Excessive energy can be allocated to other energy needs, such as electricity so that people can convert their current source of electrical energy from PLN to biogas.
\end{abstract}

\section{INTRODUCTION}

Indonesia is currently facing severe energy challenges. These challenges can be divided into at least three major groups: the low level of electrification, the dependence on fossil energy sources, and the dependence on the traditional use of biomass energy [1]. The use of fossil energy sources for energy generation needs cannot be done forever because they are limited in number and will run out in their time. It is estimated that fossil energy sources or fuels such as coal, petroleum, and natural gas will be exhausted by 2050 [2]. The consumption of fossil energy sources in Indonesia, especially petroleum, is classified as high at 96 percent, with 48 percent petroleum, 18 percent gas, and 30 percent coal of total national energy consumption [3].

Responding to the issue of energy sources, an effort is needed to meet the energy needs of the Indonesian people. The Indonesian Government has set targets for energy use as set out in Presidential Regulation [4]. In article 2, Paragraph 2 states how to achieve an energy elasticity lower than one, implementing an energy-independent village program. If the program is developed in rural areas, it will create energyindependent communities, particularly to meet consumers' daily energy needs. If people in rural areas can develop this program, energy-independent communities will be created, in particular, to meet the daily energy needs of households. Indonesia's energy sources are diverse, primarily consisting of wind, sunshine, and biogas [5].

The Eastern Java Provincial Government, particularly the Department of Energy and Mineral Resources of the Province of East Java, has planned a 2014-2019 work program to address energy issues in the context of the Presidential Regulation of the Republic of Indonesia Number 5 of 2006 on energy policy. The Energy and Electricity Inventory, Utilization and Control Program is planned by the Ministry of Energy and Mineral Resources of East Java Province. One of the activities planned by the Department of Energy and Mineral Resources of East Java is the identification of energyindependent villages.

The Pasuruan Regency's mission is to develop and maintain villages that are prosperous in the agricultural, plantation, fishery, and livestock sectors. Pasuruan Regency has allocated IDR 233.8 billion for the village to help development [6]. Local people's development in Pasuruan district in agriculture focuses on increasing food crop production, productivity, and quality, horticultural production, and livestock productivity [7].

According to the regulations mentioned above, villages capable of operating autonomously are Puspo Village, Jimbaran District, Pasuruan Regency. This community has a population of 7,018 people with an area of 645,683 kilometers. The majority of Jimbaran Village residents are cattle breeders, and they work in that line of business employing approximately 1663 people [6]. This data shows how Jimbaran 
Village has potential. Community empowerment [8] could be optimized to use biogas potency in this village.

Currently, the livestock sector has good economic prospects due to the high demand for livestock products [6]. However, the Jimbaran Village people are not yet aware of another potential of the livestock sector, namely the processing of waste into biogas energy. The waste produced by cow dung is quite a lot and processed into biogas [9], but the fact is that in Jimbaran Village, the livestock waste is left alone without any further management. The people of Jimbaran view livestock manure as something completely useless. They do not realize that livestock manure can serve as a raw material for developing wind farms and solar panels.

Besides being converted into biogas, livestock waste is also processed into compost used to produce coffee and cloves. Some residents of Jimbaran Village are currently using this waste as fertilizer. However, utilization is not optimal, as it is not used during the rainy season, but only during the dry/dry season. This is because the Community method of processing livestock waste into fertilizer is still straightforward. Drying cow dung depends on the sun's rays and heat during the dry season. If adequately managed, cow dung processing into organic fertilizer can occur in 2 seasons; dry and rainy. Therefore, it is necessary to carry out a further review of the use of cow manure in organic fertilizers with more optimal utilization.

Based on existing data from the Ministry of Development of Disadvantaged Areas and Transmigration (2015), Jimbaran Village is one of the underdeveloped villages with a Developing Village Index (IDM) value of 0.599 [10]. This value is indicated by 81 low-income families, which is equivalent to $7 \%$ and supported by a lack of infrastructure. The existence of low-income families may be due to a lack of development of the potential for natural resources by the Jimbaran Village government [10] and lack of infrastructure development [11]. The potential is not optimally developed due to a lack of knowledge of existing human resources, particularly about developing the treatment of livestock waste. Based on these potentials and problems, it is necessary to plan according to Jimbaran Village's typology to improve the economic conditions and welfare of the community through Energy Independent Village (EIV).

\section{DATA COLLECTION METHOD}

Data collection methods are techniques or methods that researchers can use to collect data [12]. Data collection is the most strategic step in research because the primary purpose is to obtain data [13]. The following are data collection techniques and analysis techniques used in this study like observation, interviewed with the respondent, documentation and literature study.

\subsection{Data collection}

\subsubsection{Observation}

Observation is a technique of collecting data through direct observation in the field or on location $[14,15]$.

Observations are made to observe and understand the existing conditions directly, as well as observe and understand the potential of livestock and observe the physical and nonphysical conditions of the supporting facilities for managing cow manure in Jimbaran Village.

\subsubsection{Interview}

Interviews were conducted to determine the existing conditions in Jimbaran Village from sources, both residents and parties involved in cattle farming, and to know the perceptions of residents about the condition of cow dung waste in the area.

\subsubsection{Documentation}

Documentation can contain descriptions, explanations, and computer-generated prints. Documentation is carried out to take several pictures of facilities and infrastructure, potential breeders, physical potential in the form of agricultural land or gardens to complement the data from the primary survey.

\subsubsection{Literature study}

The function of the literature study is to add references to the report content and increase knowledge. Secondary data can also be obtained through scientific journals, Laws, Indonesian National Standards on rural issues, and Energy Independent Villages (DME). An agency study is a data collection technique carried out by reviewing the relevant agencies in charge of having the data needed to compile a research report.

\subsection{Analysis technique}

Data analysis techniques are methods or means of getting data into information so that the characteristics of the data are easy to understand and useful for finding solutions to problems, which mainly study issues. The analysis used in this research consists of biogas analysis, which consists of supply analysis, demand analysis, and energy performance analysis. The following is a further explanation for the analysis that we are using:

\subsubsection{Supply analysis}

Supply analysis is one of the analytical tools used to make biogas energy available to the public. Furthermore, this analysis can be used to determine the interest of Jimbaran Village, Puspo District, in biogas energy. Biogas energy is produced from cattle waste that is processed into biogas by the daily use of cattle manure. Biogas is useful to support the daily needs of the people of Jimbaran Village, Puspo District. The method for calculating the production of biogas (Eq. (1)) is as follows [16]:

$$
S_{t}=\sum \text { catles } x \text { waste production } x Y_{t}
$$

where:

$\mathrm{S}_{\mathrm{t}} \quad$ : The amount of biogas available ( $\mathrm{m}^{3} /$ days $)$

Ecows : Number of cows (head)

$\mathrm{Y}_{\mathrm{t}} \quad$ : Potential gas produced $\left(\mathrm{m}^{3} / \mathrm{kg} /\right.$ days $)$

\subsubsection{Demand analysis}

This demand analysis determines the amount of energy needed by Jimbaran Village, Puspo District, and Pasuruan Regency. Biogas energy itself has benefits, namely to replace kerosene, which is for cooking. The calculation of biogas energy is fundamental; this is because it is to find out how much the people of Jimbaran village need for biogas energy and how much the people of Jimbaran Village use this energy. According to [16], the calculation of biogas energy needs is as follows (Eq. (2)):

$$
\text { Demand }=\frac{E C}{\mathrm{PSE}}
$$


Analysis of household biogas needs calculate using the conversion coefficient of biogas equivalence to kerosene [17] with the formula (Eq. (3)):

$$
E C=\Sigma \text { kerosene needs } x(1 / 0,62)
$$

\subsubsection{Energy fulfilments analysis}

Energy fulfillment in Jimbaran Village calculating after knowing the Energy Supply and Demand. The following is an analysis formula for energy fulfillment (Eq. (4)):

$$
\text { Energy Fulfilments }=\frac{\text { Supply }}{\text { Demand }} \times 100 \%
$$

\section{RESULTS AND DISCUSSION}

\subsection{General characteristics}

Jimbaran Village is part of the Puspo district with 895 hectares, while hills dominate the Jimbaran Village. There are still many potential natural resources from this vast area that have not been explored. Geographically, Jimbaran Village locating in the southern part of Pasuruan Regency (Figure 1). The people of Jimbaran Village's daily lives are farming, dairy farmers, goat farmers, construction workers, and others. The community is actively planting elephant grass as feed for dairy cows along the village road. The distance from the capital of the district is $5 \mathrm{~km}$ and takes 15 minutes. In the meantime, the distance from the district's capital is $33 \mathrm{~km}$ and takes about 2 hours. The administrative boundaries of Jimbaran Village [18] to the north bordering Ngantungan Village, Pasrepan District; to the east bordered by Keduwung Village, Puspo District; to the south is Baledono Village, Tosari District; to the west is bordered by Puspo Village, Puspo District.

\subsection{Population}

The distribution of the population in Jimbaran village is divided into eight hamlets, namely Jimbaran Hamlet, Jurang Kecambah Hamlet, Tanjek Wetan Hamlet, Tanjek Kulon Hamlet, Kebonsari Hamlet, Rejosari Hamlet, Jambu Hamlet, Setro Hamlet. Jimbaran Village has a population of 7,083 people with a total number of households are 1912.

Table 1. Number of households in each hamlet

\begin{tabular}{cc}
\hline Hamlets & Jumlah KK \\
\hline Jurang Kecambah & 233 \\
Jimbaran & 159 \\
Setro & 373 \\
Kebonsari & 228 \\
Tanjek Wetan & 261 \\
Tanjek Kulon & 205 \\
Jambu & 218 \\
Rejosari & 235 \\
\hline Total & $\mathbf{1 . 9 1 2}$ \\
\hline Sources: Primary Survey, 2018 and 2020
\end{tabular}

Based on Table 1, it can be seen that the number of population distributions in each hamlet in Jimbaran Village is different. Setro hamlet has the most extensive population distribution, based on the number of households, with 373 households. Besides, it is also known that the smallest population of Jimbaran Village is based on the number of families located in Jimbaran Hamlet with a total of 159 families.

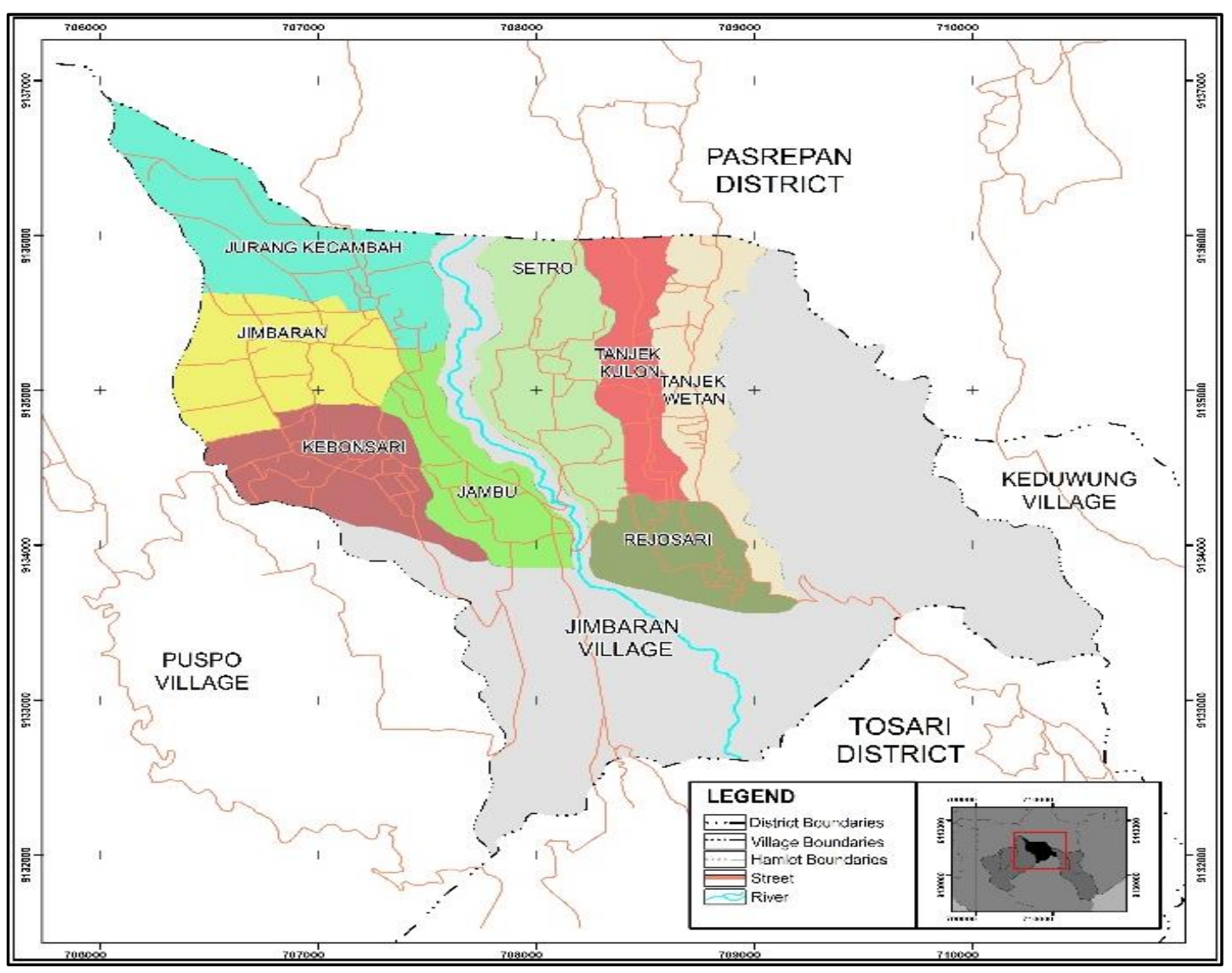

Figure 1. Jimbaran village administration map 
Jimbaran Village has a variety of activities to support the livestock and agriculture sectors of the economy. This activity can be seen through agricultural commodities to find the results of existing commodities and superior commodities in Jimbaran Village. The economic activities (type of livelihood) of Jimbaran Village can be derived from interviews and literature studies. Jimbaran Village has a variety of activities that are used to support their economy, namely as follows:

Table 2. Number of workers per livelihood

\begin{tabular}{cc}
\hline Type of Livelihood & Number of Workers (person) \\
\hline Farmers and breeders & 3.300 \\
Traders & 690 \\
Civil servants & 16 \\
Mechanic & 5 \\
Driver & 40 \\
General employees & 57 \\
Carpenter & 200 \\
Teacher & 13 \\
\hline
\end{tabular}

Source: Profile of Jimbaran Village, 2020

When looking at Table 2, it is clear that there are a large number of workers in Jimbaran Village. The majority of the village's livelihoods are livestock farming, which provides jobs to 3,300 people. This village's second most engaged farmers are traders, total almost 700 people. In Jimbaran Village, the least livelihood is as a mechanic. Apart from being a breeder, Jimbaran Village residents are traders and a farmer for the trees.

\subsection{Land used}

Jimbaran Village, located in Puspo District, Pasuruan Regency, has 895 ha, various types of land uses (Table 3). In the Jimbaran area, agriculture is divided into plantations and livestock. The agricultural products have different middlemen into the Pasrepan Market, Puspo Market, and some are directly sold to Lumajang, such as sengon.

In the Jimbaran area, agriculture is divided into plantations and livestock. The agricultural products have different middlemen into the Pasrepan Market, Puspo Market, and some are directly sold to Lumajang, such as sengon. Plantation is located in the Jimbaran Village in the north of Bali with an area of 400.58 ha of cloves, coffee, petai, and avocado. Most of Jimbaran Village's plantations use the intercropping system which allows for plants of different types to be grown in the same plot of land. The best commodity products are substitutes for poorly managed commodities. Some of the oldest breeders in Jimbaran Village are dairy farmers.

\subsection{Analysis of animal waste treatment}

Jimbaran Village has the potential to become a suitable place for dairy cattle, as well as feces and urine which can be used as a source of renewable energy. To assess the energy potential in livestock waste in Jimbaran Village, the needs of the community will be evaluated. Analysis of cattle waste processing in Jimbaran Village is divided into three parts, including supply, demand and energy utilization.

Table 3. Land used in Jimbaran village

\begin{tabular}{cc}
\hline Use of Land & Area (ha) \\
\hline Forest & 403.08 \\
Settlement & 85.22 \\
Trade and services & 0.36 \\
Government and public services & 0.08 \\
Worship & 1.43 \\
Education & 1.16 \\
Health & 0.06 \\
Funeral & 2.88 \\
Garden & 400.58 \\
Industry & 0.02 \\
Field & 0.13 \\
\hline Total & $\mathbf{8 9 5}$ \\
\hline Sources: Primary Survey, 2018 and 2020
\end{tabular}

The calculation of energy supply in Jimbaran Village is based on the availability of dairy cattle, their average production and the availability of cow dung gas. There are 5976 cows in Jimbaran Village The first assumption is one cow used for feces and urine can produce waste of approximately 25 kilograms each day [19]. The data is analyzed assuming that the number of livestock is fixed and that it is not reduced. The sum of the existing energy supply in Jimbaran Village.

On the basis of Table 4, it can be seen that the energy supply in Jimbaran Village is $103,086 \mathrm{~m} 3 /$ month. This amount is very large so that it can be used as a source of energy for cooking in the Jimbaran Village community. If the people of Jimbaran have a residual supply of cooking energy, the remaining supply can be used for other energy needs, such as electricity.

Demand is a tool to find out how much energy people need to cook. The analysis of household biogas needs is calculated using the conversion coefficient of biogas equivalent to other fuels, in this case, LPG and firewood used by the Jimbaran Village people. Based on the preliminary survey results, the average LPG gas required by one household per month is three $3 \mathrm{~kg}$ LPG gas cylinders. The average use of firewood for one household per month is $150 \mathrm{~kg}$. Household biogas demand analysis is calculated by comparing the energy consumption required with the LPG or firewood equivalent conversion coefficient. The demand calculation was dividing into two parts: the demand for breeders and the demand for nonbreeders. The supply of biogas comes from breeders, so if there is any remaining supply of biogas left from the farmer's household, it can be distributed to non-breeders in Jimbaran Village (Table 5). The following is a table on energy use in Jimbaran Village:

Table 4. Existing energy supply calculation

\begin{tabular}{|c|c|c|c|}
\hline Energy conversion & $\begin{array}{c}\text { Energy Conversion } \\
\text { Provisions [20] }\end{array}$ & $\begin{array}{c}\text { Biogas conversion results } \\
\text { (Cattle waste production } x \text { Yt) }\end{array}$ & $\begin{array}{l}\text { Supply ( } \sum \text { cows } x \text { cattle waste } \\
\text { production } x \text { Yt) }\end{array}$ \\
\hline $\begin{array}{c}\text { Animal Manure }(\mathrm{kg}) \text { - Methane } \\
\text { gas produced }\left(\mathrm{m}^{3}\right)\end{array}$ & $\begin{array}{c}1 \mathrm{~kg} \text { of manure produces } 0.023 \\
\mathrm{~m}^{3} \text { of methane gas }\end{array}$ & $\begin{array}{c}25 \mathrm{~kg} \times 0.023 \mathrm{~m}^{3}=0.575 \mathrm{~m}^{3} / \\
\text { day or } 17.25 \mathrm{~m}^{3} / \text { month }\end{array}$ & $\begin{array}{c}5976 \times 0.575 \mathrm{~m}^{3}=3.436,2 \mathrm{~m}^{3} / \text { day } \\
\text { or } 103.086 \mathrm{~m}^{3} / \text { month }\end{array}$ \\
\hline
\end{tabular}

Sources: Primary Survey, 2018 and 2020 
Table 5. Existing energy demand calculation

\begin{tabular}{cccccc}
\hline \multirow{2}{*}{ Family } & $\begin{array}{c}\text { Type of } \\
\text { Energy used }\end{array}$ & $\begin{array}{c}\text { Number of } \\
\text { households }\end{array}$ & $\begin{array}{c}\text { Energy Consumption } \\
\text { (per month) }\end{array}$ & $\begin{array}{c}\text { Energy source } \\
\text { comparison (kg) }\end{array}$ & $\begin{array}{c}\text { Demand (KE / PSE x } \\
\text { number of households) }\end{array}$ \\
\hline \multirow{2}{*}{ Breeder } & LPG & 783 & 3 tube LPG 3 kg & 0.46 & 15319.56 \\
\cline { 2 - 6 } & Firewood & 830 & $150 \mathrm{~kg}$ & 3.5 & 34583.33 \\
\hline \multirow{2}{*}{$\begin{array}{c}\text { Non } \\
\text { Breeder }\end{array}$} & LPG & 135 & 3 tube LPG 3 kg & 0.46 & 3228.26 \\
\hline \multicolumn{7}{r}{} & Firewood & 164 & $150 \mathrm{Kg}$ & 3.5 & 6833.33 \\
\hline
\end{tabular}

Sources: An analysis, 2020

A sustainable energy system can be created after analyzing the energy demand and supply. On the basis of the results of the above calculations of supply and demand, it can be seen that supply is greater than demand. This means that Jimbaran Village can meet its own energy needs. The following is a calculation of the energy performance analysis in Jimbaran Village:

$$
\begin{gathered}
\text { Energy fulfillment }=\frac{\text { Supply }}{\text { Demand }} \times 100 \% \\
\text { Energy fulfillment }=\frac{103.086}{59.964,49} \times 100 \% \\
\text { Energy fulfillment }=172 \%
\end{gathered}
$$

As can be seen from the energy needs calculation above, we have ample energy to cook our meals independently. This calculation shows that the energy captured through biogas production is sufficient to be used as an energy source. The extra energy from the biogas can be allocated to other energy needs like electricity or heating, so people can switch to using the biogas instead of natural gas. Besides the considerable biogas energy potential, there are still other environmental problems. The villagers of Jimbaran have not yet used biogas. Some people do not understand what bio-gas is. The community does not want to use biogas because it is hard to manufacture and requires a considerable investment.

\subsection{Development concept}

Many of the people in Jimbaran Village work as farmers and breeders. In order, there are approximately 3,300 people who work as farmers and breeders, 76.75 percent. Members of this profession spreading across eight villages in Jimbaran. The waste produced by dairy cows is cow manure, which can be used for agriculture. Goods management of waste is vital because waste minimizes negative impacts on the surroundings, such as soil pollution, water pollution, air pollution, and infectious diseases. Unfortunately, cow manure in Jimbaran Village has not been used as biogas, or as an alternative energy source.

From the dairy cattle waste analysis, a large number of benefits can be derived: a biogas reactor can be imagined. The plan is aimed at creating a communal biogas reactor in all eight hamlets in Jimbaran Village. The plan to build this biogas reactor that will be operational until 2038, the type of biogas reactor will be the dome type, one communal biogas unit that can serve five residences of the community Jimbaran Village. Recall that the number of communal biogas reactors in each village is listed below.

In Table 6 and Figure 2 the number of houses in Jimbaran village which is divided into eight hamlets is 1557 , the number of Jurang Kecambah hamlet is 205, the number of Dusun Jimbaran is 151, the number of Jambu hamlet is 184, the number of Kebonsari hamlet is 201, the number of Tanjek Wetan hamlet is 229, the number of Tanjek Kulon hamlet is 173 , and the number of Rejosari hamlet is 211 . So that the planning of the number of biodigesters or biogas reactors in Jimbaran Village which is divided into each hamlet is 41 units of Jurang kecambah Hamlet, 30 units of Jimbaran Hamlet, 37 units of Jambu Hamlet, 40 units of Kebonsari Hamlet, 65 units of Setro Hamlet, 46 units of Tanjek Wetan Hamlet, Dusun 35 units of Tanjek Kulon, 42 units of Rejosari Hamlet communal biogas reactors, this is assuming that one communal bogas reactor has a service scale of 5 residents' houses in each hamlet in Jimbaran Village.

Table 6. Plan for the number of biodigester in the village

\begin{tabular}{ccc}
\hline Hamlet & $\begin{array}{c}\text { Number of } \\
\text { Houses }\end{array}$ & $\begin{array}{c}\text { Biodigester Number } \\
\text { Plan }\end{array}$ \\
\hline Jurangkecambah & 205 & 41 \\
Jimbaran & 151 & 30 \\
Jambu & 184 & 37 \\
Kebonsari & 201 & 40 \\
Setro & 323 & 65 \\
Tanjek wetan & 229 & 46 \\
Tanjek kulon & 173 & 35 \\
Rejosari & 211 & 42 \\
\hline Total & $\mathbf{1 5 5 7}$ & $\mathbf{3 3 6}$ \\
\hline
\end{tabular}

The use of cow manure is to create an energy-independent village by having a scale of service throughout the village that can be used to meet the community's daily needs. It can be used for cooking, powering generation, and being alternative energy - organic fertilizer produced in Jimbaran village, used in the agricultural sector. Table 7, examines the supply and demand of methane gas and studies this gas's ability to provide cooking energy. The biogas energy plant in Jimbaran Village is the primary project in the development plans from 20212041.

According to Table 7 . The ability to satisfy energy needs 172 percent, with energy left over means the energy can still be used. It was a $172 \%$ increase in energy fulfillment in 2021. Biogas energy can be used to fuel cooking and provide electricity. Nonetheless, energy fulfillment has experienced a decrease, but it has still been above $100 \%$. However, there is still enough electricity to fulfill the local community's needs and can be used for daily activities such as cooking. Suppose the community utilizes alternative biogas energy to process their agricultural products. In that case, this will result in increased community income and people will be able to obtain their fuel needs without purchasing LPG or firewood. 


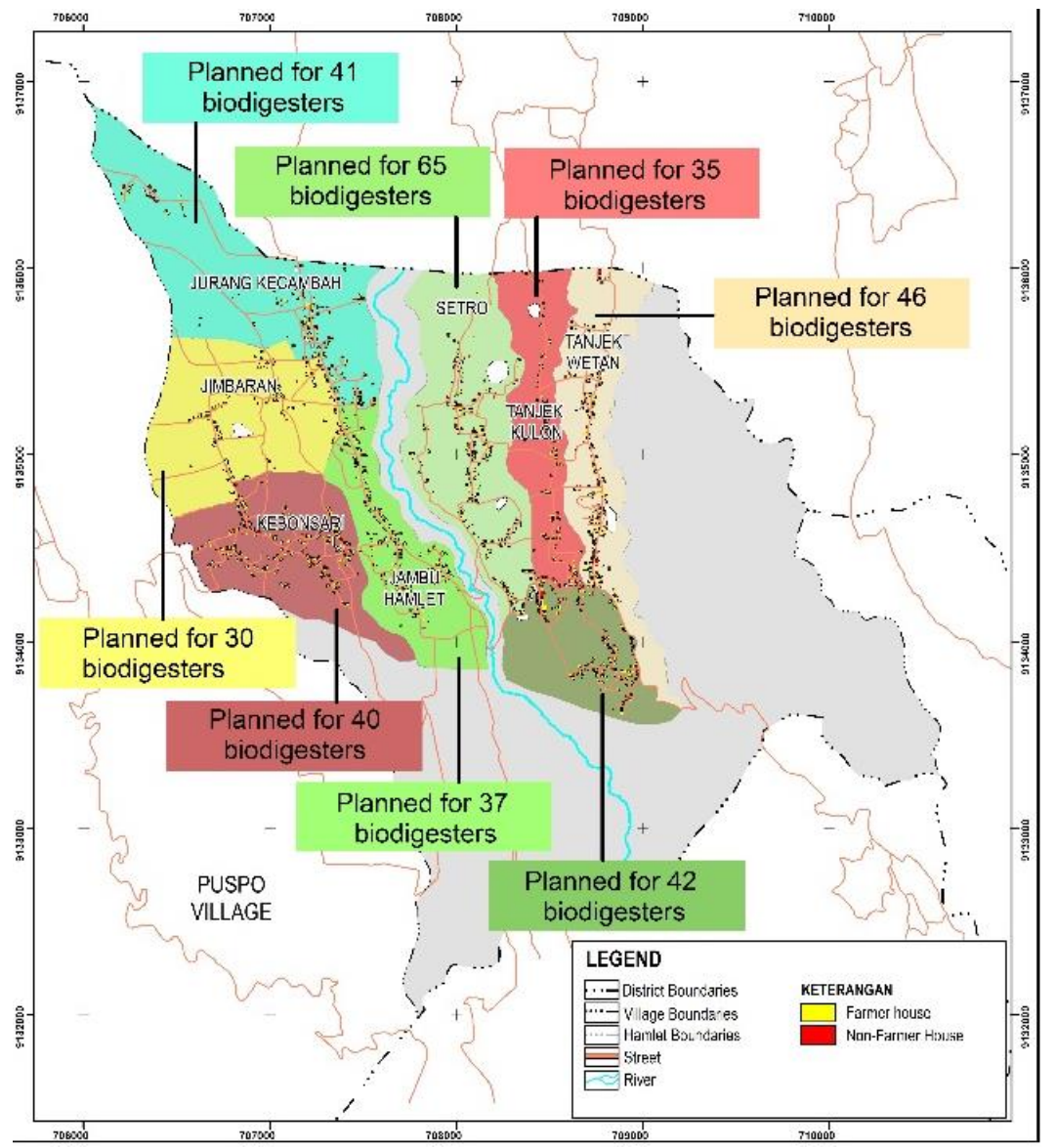

Figure 2. Biodigester manufacturing plan

Table 7. Fulfillment of Biogas Energy for Cooking in Jimbaran Village

\begin{tabular}{|c|c|c|c|c|c|}
\hline Years & $\begin{array}{c}\text { Number of } \\
\text { Cows }\end{array}$ & $\begin{array}{c}\text { Manure Production (Kg / } \\
\text { Year) }\end{array}$ & $\begin{array}{c}\text { Energy of Biogas } \\
\text { (m3/year) }\end{array}$ & $\begin{array}{c}\begin{array}{c}\text { Demand for Cooking } \\
(\mathrm{m} 3 / \text { year })\end{array} \\
\end{array}$ & Fulfillment \\
\hline 2021 & 5976 & 53784000 & 1237032 & 59885.370 & $172 \%$ \\
\hline 2022 & 5984 & 53856000 & 1238688 & 60656.293 & $170 \%$ \\
\hline 2023 & 5994 & 53946000 & 1240758 & 61427.217 & $168 \%$ \\
\hline 2024 & 6004 & 54036000 & 1242828 & 62198.141 & $167 \%$ \\
\hline 2025 & 6014 & 54126000 & 1244898 & 62969.065 & $165 \%$ \\
\hline 2026 & 6024 & 54216000 & 1246968 & 63739.989 & $163 \%$ \\
\hline 2027 & 6034 & 54306000 & 1249038 & 64510.913 & $161 \%$ \\
\hline 2028 & 6044 & 54396000 & 1251108 & 65281.837 & $160 \%$ \\
\hline 2029 & 6054 & 54486000 & 1253178 & 66052.761 & $158 \%$ \\
\hline 2030 & 6064 & 54576000 & 1255248 & 66823.685 & $157 \%$ \\
\hline 2031 & 6074 & 54666000 & 1257318 & 67594.609 & $155 \%$ \\
\hline 2032 & 6084 & 54756000 & 1259388 & 68365.533 & $154 \%$ \\
\hline 2033 & 6094 & 54846000 & 1261458 & 69136.457 & $152 \%$ \\
\hline 2034 & 6104 & 54936000 & 1263528 & 69907.380 & $151 \%$ \\
\hline 2035 & 6114 & 55026000 & 1265598 & 70678.304 & $149 \%$ \\
\hline 2036 & 6124 & 55116000 & 1267668 & 71449.228 & $148 \%$ \\
\hline 2037 & 6134 & 55206000 & 1269738 & 72220.152 & $147 \%$ \\
\hline 2038 & 6144 & 55296000 & 1271808 & 72991.076 & $145 \%$ \\
\hline 2039 & 6154 & 55386000 & 1273878 & 73762.000 & $144 \%$ \\
\hline 2040 & 6164 & 55476000 & 1275948 & 74532.924 & $143 \%$ \\
\hline 2041 & 6174 & 55566000 & 1278018 & 75303.848 & $141 \%$ \\
\hline
\end{tabular}

Sources: An analysis, 2020

\section{CONCLUSION}

Based on our findings, we believe several things regarding the implementation of the communal biodigester in Jimbaran Village, Puspo District, Pasuruan Regency:

- In Jimbaran Village, cattle breeders are made up of 1663 family heads who own 5,976 dairy cows. This data shows how Jimbaran Village has potential. While the livestock sector has a great outlook, the people in Jimbaran Village have not yet been aware of the opportunities from processing waste into biogas energy. The purpose of using biogas energy is to reduce fossil energy use in favor of 
renewable energy and improve the environment through livestock manure.

- $\quad$ The village contains 299 non-farmer households. The fuel used in the village is LPG and firewood. Using the demand analysis results, the total biogas demand for nonfarming consumers is $10,061.59$ cubic meters per month. Meanwhile, they produce 100,086 tons of products each month. So, it can be concluded that there is a variety of breeding stock with which non-breeders can be successfully serviced in Jimbaran Village.

- Based on the calculation of energy dissipation, it can be seen that energy dissipation is more than 100 percent, which means there is excess energy lost from the existing biogas. The extra energy from the biogas can be allocated to other energy needs like electricity or heating, so people can switch to using the biogas instead of natural gas.

\section{REFERENCES}

[1] Surendra, K.C., Takara, D., Hashimoto, A.G., Khanal, S.K. (2014). Biogas as a sustainable energy source for developing countries: Opportunities and challenges. Renew. Sustain. Energy Rev., 31: 846-859. https://doi.org/10.1016/j.rser.2013.12.015

[2] Rosyadi, I., Setiawan, I., Haryadi, Suhendri. (2016). Kajian tentang penggunaan bahan bakar biosolar murni dan campurannya menggunakan minyak jarak pada mesin disel satu silinder. J. Tek. Mesin Untirta, II(2): 5463.

https://jurnal.untirta.ac.id/index.php/jwl/article/view/13 67/1089.

[3] BPPT. (2014). Pengembangan Energi untuk Mendukung Program Substitusi BBM, vol. 1 . https://www.bppt.go.id/berita-bppt/outlook-energiindonesia-2014-untuk-pengelolaan-energi-yang-lebihbaik.

[4] Presidential Regulation, Presidential Regulation of the Republic of Indonesia No 5 of 2006 on National Energy Polic.

2006. https://policy.asiapacificenergy.org/node/3297.

[5] Yuaningsih, L., Febrianti, A., Kamran, H. (2020). Reducing $\mathrm{CO}_{2}$ emissions through biogas, wind and solar energy production: Evidence from Indonesia. Int. J. Energy Econ. Policy, 10(6): 684-689. https://doi.org/10.32479/ijeep.10590

[6] BPS Pasuruan. (2019). Pasuruan in Figure 2019. Pasuruan Regency, 2019 https://pasuruankab.bps.go.id/publication/2019/08/16/9e be 327b25852ba77d32a661/kabupaten-pasuruan-dalamangka-2019.html.

[7] Kabupaten Pasuruan, RPJMD Kabupaten Pasuruan 2018-2023 (Regional Development Plan 2018-2033). http://jdih.pasuruankab.go.id/index.php/hukum/detail/re ncana-pembangunan-jangka-menengah-daerahkabupaten-pasuruan-tahun-20182023, 2019, pp. 1-419.

[8] Prayitno, G., Hakim, A., Meidiana, C. (2020). Factors influencing the willingness to join $\mathrm{CBO}$ biogas self-help group in Mulyorejo urban village and Karangnongko village in Malang, Indonesia. Evergreen, 7(4): 468-480. https://doi.org/10.5109/4150466

[9] Prayitno, G., Hakim, A., Meidiana, C. (2021). Community participation on the self help group of methane gas (Biogas) management as renewable energy in Indonesia. Int. J. Energy Econ. Policy, 11(1): 200-211. https://doi.org/10.32479/ijeep.10595

[10] H. Hamidi et al. (2015). Indeks Desa Membangun 2015. Kementrian Desa Pembangunan Daerah Tertinggal dan Transmigrasi. https://idm.kemendesa.go.id.

[11] Nugraha, A.T., Prayitno, G., Situmorang, M.E., Nasution, A. (2020). The role of infrastructure on economic growth and income inequality of Indonesian. Econ. Sociol., 13(1): 102-115. https://doi.org/10.14254/2071789X.2020/13-1/7

[12] Riduwan, Skala Pengukuran Variabel-Variabel Penelitian. Bandung: $\quad$ ALFABETA, 2004. https:/cvalfabeta.com/product/cskala-pengukuranvariabel-variabel-penelitian/.

[13] Sugiyono. (2012). Metode Penelitian Kuantitatif, Kualitatif dan $\mathrm{R}$ \& $\mathrm{D}$. Bandung: Alfabeta. https://cvalfabeta.com/product/metode-penelitiankuantitatif-kualitatif-dan-rd-mpkk/.

[14] Moeliono, Rianingsih, D. (1996). Kebijakan dan Strategi Penerapan PRA dalam Pengembangan Program. Bandung: Driya Media.

[15] Prayitno, G., Subagiyo, A. (2018). Membangun Desa. Malang: UB Press. https://auth.ub.ac.id/module.php/core/loginuserpass.php ?AuthState $=29$ eba524710eb6b01ac2d8ad5890cf8c072 9cdc64d\%3Āhttps\%3A\%2F\%2Fauth.ub.ac.id\%2Fsaml 2\%2Fidp $\% 2$ FSSOService.php $\% 3$ Fspentityid $\% 3$ Dgoogl e.com $\% 252 \mathrm{Fa} \% 252 \mathrm{Fub}$. ac.id $\% 26$ cookieTime $\% 3 \mathrm{D} 1636$ $726313 \% 26 \mathrm{R}$.

[16] Asmara, A., Hutagaol, M.P., Salundik, S. (2013). Analisis potensi produksi dan persepsi masyarakat dalam pengembangan biogas pada sentra usaha ternak sapi perah di kabupaten bogor. J. Agribisnis Indones., 1(1): 71. https://doi.org/10.29244/jai.2013.1.1.71-80

[17] Mineral, P.D. (2010). Indonesia Energy Outlook 2010. Kementrian Energi dan Sumber Daya Mineral. Jakarta.

[18] T.G. of J. Village, RPJM Jimbaran Village (Village Mid Term Planning 2015-2020). 2014. https://www.google.com/search?client $=$ safari\&rls $=$ en $\&$ $\mathrm{q}=\mathrm{RPJM}+$ Desa + Jimbaran\&ie $=\mathrm{UTF}-8 \& \mathrm{oe}=\mathrm{UTF}-8,2014$

[19] Hanif, A. (2010). Studi Pemanfaatan Biogas Sebagai Pembangkit Listrik 10 kw Kelompok Tani Mekarsari Desa Dander Bojonegoro Menuju Desa Mandiri Energi. Institut Teknologi Sepuluh November, 2010. https://www.google.com/search?client $=$ safari\&rls=en\& q=A.+Hanif,+"'Studi+Pemanfaatan+Biogas + Sebagai + Pe mbangkit+Listrik $+10+\mathrm{kw}+$ Kelompok+Tani+Mekarsari + Desa+Dander+Bojonegoro+Menuju+Desa+Mandiri+E nergi.,"+Institut+Teknologi+.

[20] Wahyuni, Y., Larasati, Z. (2017). Identifikasi nilai embodied energy sebagai upaya mitigasi energi dalam perencanaan bangunan. J. Lingkung. Binaan Indones., 6(1): 9-15. https://doi.org/10.32315/jlbi.6.1.9 